\title{
Micronucleus test in erythrocytes of Barbus plebejus (Teleostei, Pisces) from two natural environments: a bioassay for the in situ detection of mutagens in freshwater
}

\author{
Sandra Minissi, Eleonora Ciccotti ${ }^{*}$, Marco Rizzoni \\ Laboratorio di Ecologia Sperimentale e Acquacoltura, Dipartimento di Biologia, Unicersità degli Studi di Roma 'Tor Vergata', via della \\ Ricerca Scientifica, 00133 Rome, Italy
}

Received 30 May 1995; revised 13 September 1995; accepted 8 November 1995

\begin{abstract}
Erythrocyte micronucleus frequencies in wild fish from two riverine environments and in fish reproduced and reared under controlled conditions (control group) were compared, with the aim to evaluate the suitability of the MN test for the in situ detection of mutagens in freshwaters. Fish were caught in different months in two rivers of central Italy which have different pollution levels. As indicator species, the barbel (Barbus plebejus) was chosen because of its ecological significance. Blood samplings were performed on wild fish immediately after capture and repeated at different time intervals on the same individuals, which were maintained in controlled conditions after capture. A total of 10000 erythrocytes per specimen were scored. No significant differences in micronucleus frequencies were observed between the control group and fish from the unpolluted river (Mignone). A significantly higher frequency of micronuclei was observed in fish caught in the polluted river (Tiber), in comparison to both the controls and the Mignone river fish. No significant seasonal differences were observed. Barbels examined 50 and 100 days after capture presented a remarkable decrease in micronucleus frequency in comparison with the frequency observed in barbels at capture. The micronucleus test in fish erythrocytes was shown to be a sensitive bioassay for detecting mutagenic pollution in fresh water environments.
\end{abstract}

Keywords: Micronucleus; Mutagenic pollution; Fish; Bioassay

\section{Introduction}

In recent years, increasing concern about genotoxic pollution in inland and coastal waters has led to the development of many different mutagenesis test systems. Water and sediment samples can be tested

\footnotetext{
* Corresponding author. Tel.: +39 (6) 2026187/8; Fax: + 39 (6) 2026189
}

for mutagenicity under laboratory conditions using biological systems such as bacteria, yeasts and plants. Interest has also been focused on laboratory tests using aquatic organisms such as amphibians, molluscs and fish (see Stahl, 1991 for a review). However, for the in situ investigation of mutagenic pollution effects (environmental monitoring) there is growing interest towards the use of bioindicators. For this purpose, fish are suitable organisms (Landolt and Kocan, 1983) because they play different roles 
in the trophic web, undergo bioaccumulation, respond to mutagens at low concentrations such as environmental pollutants and they activate xenobiotics through the cytochrome P450-dependent oxidative metabolism like mammals do (Goksoyr et al., 1991).

Cytogenetic analyses have been carried out in fish for different genetic end-points, under laboratory conditions, testing known mutagens as well as polluted waters (CA: Klingerman et al. (1975), SCE:
Alink et al. (1980) and MN: Hooftman and de Raat (1982); Das and Nanda, 1986), and in in situ exposure (De Flora et al., 1993). The in situ detection of environmental contaminants using fish as bioindicators has mainly been carried out in marine coastal waters (Hose et al., 1987; Hughes and Hebert, 1991).

Among the many mutagenesis assays, the micronucleus test has been successfully applied as it is simple, reliable and sensitive; furthermore it is not strongly dependent on any karyotypic characteristic

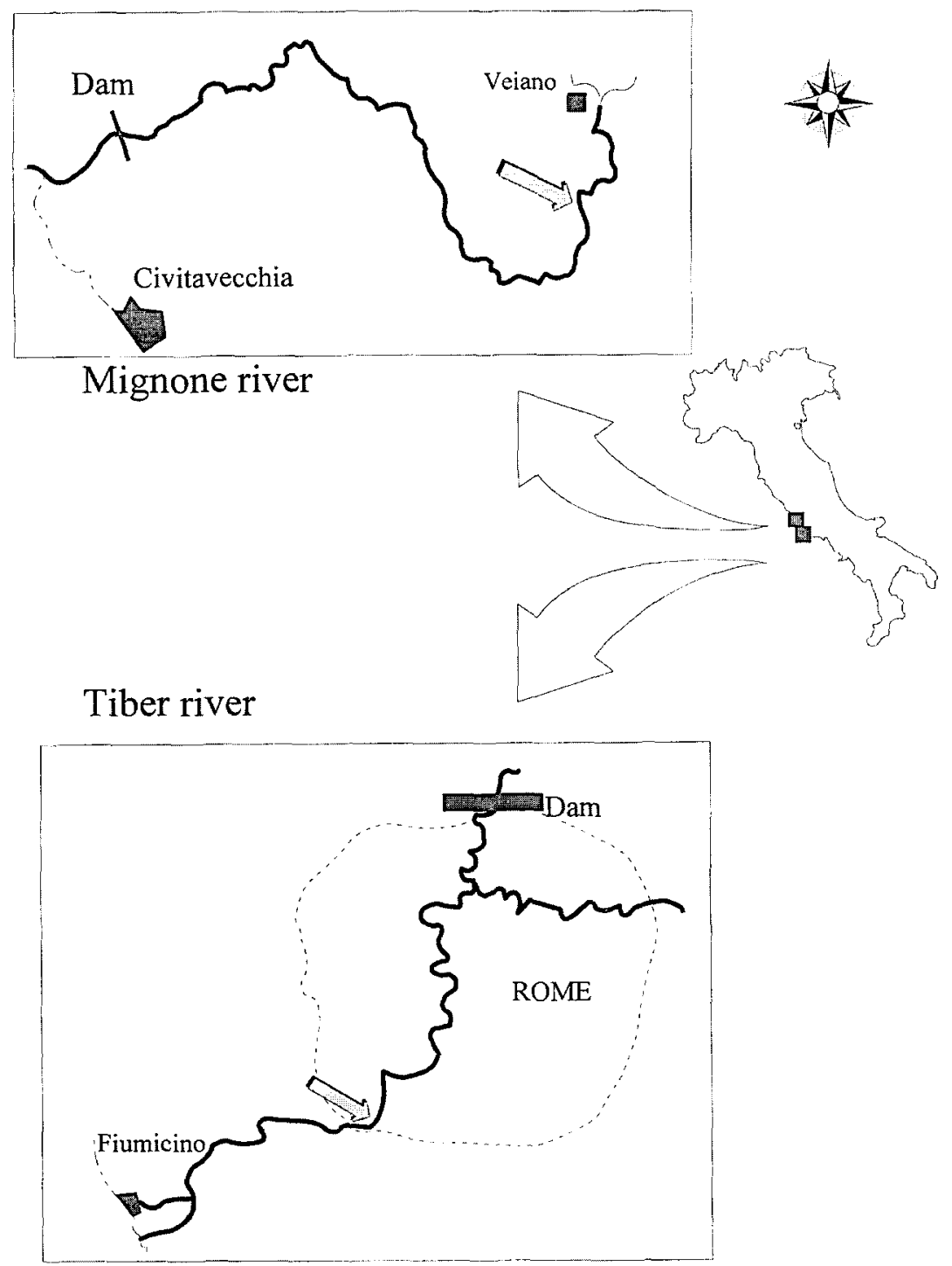

Fig. 1. Study area and sampling stations (small gray arrows) in the Mignone and Tiber rivers. 
(see Heddle et al., 1983 for a review). When fish erythrocytes are used, it is also not time consuming and without suffering for animals (EEC Dir. no. $86 / 609$ ). For all these reasons, the micronucleus test in fish erythrocytes seems to be a promising test in environmental mutagenesis investigations (Al-Sabti and Metcalfe, 1995).

In the present paper, micronucleus frequency in fish erythrocytes has been evaluated in a Teleost fish, Barbus plebejus, from two freshwater environments characterized by different pollution levels, and compared with the values observed in erythrocytes of fish reproduced and reared under controlled conditions. For one sample, micronucleus frequencies of wild fish, from both rivers, were examined at repeated time intervals, i.e. at capture and after 50 and 100 days of maintenance. The aim of the present work was to validate the sensitivity of this test system and the suitability of bioindicators in environmental monitoring.

As indicator species, Barbus plebejus was chosen because of its ecology. The barbel is a benthic feeder: living in close association with the water bed, this fish has an increased interaction with the pollutants, and thus seems to be more sensitive to pollution (Vindimian et al., 1991) than 'coarser' species. Furthermore, considering the ichthyological zonation based on fish communities structure along the river axis characteristic of temperate regions (Huet, 1949), a 'barbel zone' can be recognized, where the barbel is the dominant species. The ecological significance of this species could confirm its value as an indicator species, and the wide zoogeographic distribution of Barbus sp. in Europe could enable the comparison among different rivers by means of in situ monitoring.

\section{Materials and methods}

Wild fish were caught in two rivers of Latium (Central Italy): the Mignone and the Tiber (Fig. 1). In the Mignone river, the sampling station was chosen in the upper course, inside a Natural Reserve, where water is unpolluted (Angeletti et al., 1985). In the Tiber, the sampling station was chosen in the lower stretch (Fig. 1), downstream of the town of Rome, where water quality is poorer (Guzzini and
Pagnotta, 1990). Total ammonia and nitrates concentrations, which to some extent reflect the levels of organic pollution, amount, respectively, to $0.28-0.32$ $\mathrm{mg} / \mathrm{l}$ and $0.014-0.062 \mathrm{mg} / \mathrm{l}$ in the Mignone (Angeletti et al., 1985) and 0.61-1.47 mg/l and 2.004-1.932 $\mathrm{mg} / 1$ in the Tiber (Guzzini and Pagnotta, 1990). The Extended Biotic Index (Woodiwiss, 1978), an index based on the presence/absence of indicator taxa of the macrobenthic community (scale 1-14), allows a comparison of the water quality in the two environments to be made: its value is 10 in the Mignone station (Carchini et al., 1985), and 6 in the Tiber station (Guzzini and Pagnotta, 1990).

Samplings were carried out in May and October 1993 in the Mignone river, and in July, September and October 1993 in the Tiber. Fish size ranged between 12 and $23 \mathrm{~cm}$. Blood samples were obtained from anesthetized fish (2-phenoxyethanol $0.3 \mathrm{ppm}$ ) immediately after capture by cardiac puncture, i.e. drawing a drop of blood from the bulbus arteriosus with a heparinized syringe (needle $0.3 \mathrm{~mm}$ thick) This technique was chosen as it is suitable for this species in relation to its depressed body form, and thus less damaging than other techniques; in fact, no mortalities followed the blood samplings. The fish of the October sample, from both rivers, were transferred to the Aquaculture Laboratory, where they were maintained in facilities consisting of $3 \mathrm{~m}^{3}$ raceways fed with well water (open system). From these samples, further blood drawings were made at 50-day intervals, i.e. after 50 and 100 days of permanence in controlled conditions. These time intervals were chosen on the basis of average turnover time for erythrocytes, evaluated in 150 days (Fange, 1992). As control, a group of barbels obtained by artificial reproduction and kept in the same conditions were used.

Blood smears were fixed in absolute methanol, and then Feulgen stained $(1 \mathrm{~h}$ in Schiff reagent after acid hydrolysis $15 \mathrm{~min}, 60^{\circ} \mathrm{C}$, in $\mathrm{HCl} 1 \mathrm{~N}$ ). A total of 10000 erythrocytes were examined for each fish at the light microscope. Such a large cell number was chosen in order to detect even a weak mutagenic effect. Only cells with intact cellular and nuclear membrane were scored. Particles with color and structure similar to chromatin, whose dimensions were comprised between $1 / 5$ and $1 / 100$ of the main 

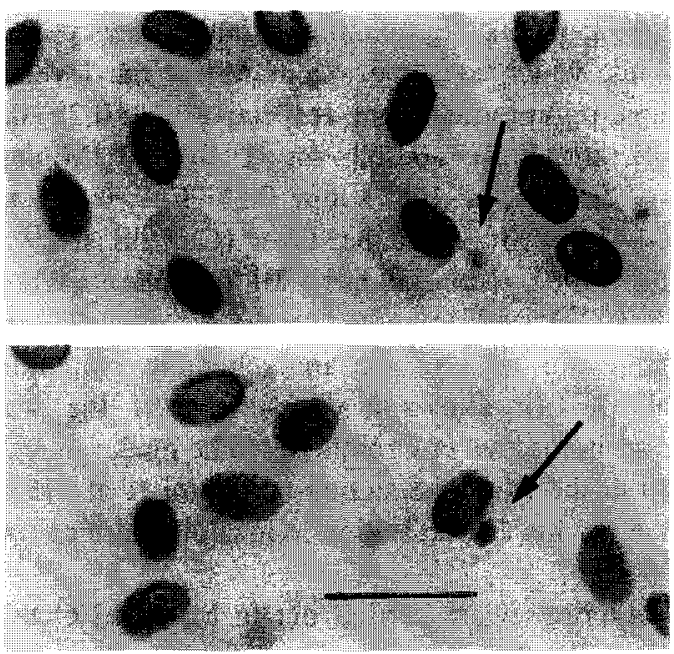

Fig. 2. Micronucleated erythrocytes in barbel $(\mathrm{bar}=10 \mu \mathrm{m})$.

nucleus were interpreted as micronuclei (MN). Only cells with one micronucleus, clearly detached from the nucleus, were scored (Fig. 2).

Mean $\mathrm{MN}$ frequencies, expressed as number of
MN per 10000 erythrocytes, were calculated for each group. MN frequencies were compared between samples and between samples and controls by means of the Mann-Whitney $U$-test $(\alpha=0.01)$. Differences, within each river, among samples caught in different months were tested with ANOVA.

\section{Results}

Results are summarized, with statistics, in Table 1. No significant differences in $\mathrm{MN}$ frequency were observed between the control group and samples from the Mignone, both in May and October, immediately after capture (Fig. 3A). In the October sample, observations on the same fish after 50 and 100 days of maintenance showed a decrease in $\mathrm{MN}$ frequency; after 100 days, MN frequency showed the same value as the control. All samples (July, September and October) from Tiber river showed, immediately after capture, a significant difference in $\mathrm{MN}$ frequency compared to the control group (Fig.

Table 1

Number of fish, mean ( \pm S.E.M.) MN frequency (MN/10000 erythrocytes) and $U$-values in comparisons between samples of Barbus plebejus :

\begin{tabular}{|c|c|c|c|c|}
\hline Samples & $n$ & $\begin{array}{l}\text { Frequency of } \\
\mathrm{MN} \pm \text { S.E.M. }\end{array}$ & $U$ & Comparison \\
\hline Control & 6 & $0.50 \pm 0.22$ & - & - \\
\hline \multicolumn{5}{|l|}{ Mignone } \\
\hline May at capture & 8 & $1.75 \pm 0.45$ & 9.0 n.s. ${ }^{h}$ & vs. control \\
\hline October at capture & 12 & $1.25 \pm 0.35$ & 22.5 n.s. & vs. control \\
\hline October after 50 days & 11 & $1.09 \pm 0.37$ & $\begin{array}{l}24.0 \text { n.s. } \\
60.5 \text { n.s. }\end{array}$ & $\begin{array}{l}\text { vs. control } \\
\text { vs. October at capture }\end{array}$ \\
\hline October after 100 days & 11 & $0.50 \pm 0.24$ & $\begin{array}{l}24.0 \text { n.s. } \\
30.5 \text { n.s. }\end{array}$ & $\begin{array}{l}\text { vs. control } \\
\text { vs. October at capture }\end{array}$ \\
\hline \multicolumn{5}{|l|}{ Tiber } \\
\hline July at capture & 30 & $3.17 \pm 0.39$ & $22.5^{\mathrm{c}}$ & vs. control \\
\hline September at capture & 24 & $3.83 \pm 0.43$ & $12.0^{\circ}$ & vs. control \\
\hline October at capture & 20 & $2.70 \pm 0.38$ & $10.5^{\circ}$ & vs. control \\
\hline October after 50 days & 20 & $1.10 \pm 0.26$ & $\begin{array}{l}40.5 \text { n.s. } \\
80.5\end{array}$ & $\begin{array}{l}\text { vs. control } \\
\text { vs. October at capture }\end{array}$ \\
\hline October after 100 days & 20 & $0.60 \pm 0.19$ & $\begin{array}{l}55.5^{\text {n.s. }} \\
48.0^{\mathrm{c}}\end{array}$ & $\begin{array}{l}\text { vs. control } \\
\text { vs. October at capture }\end{array}$ \\
\hline Mignone (all fish at capture) & 20 & $1.45 \pm 0.28$ & 31.5 n.s. & vs. control \\
\hline Tiber (all fish at capture) & 74 & $3.26 \pm 0.24$ & $\begin{array}{r}22.5^{\circ} \\
163.0^{\circ}\end{array}$ & $\begin{array}{l}\text { vs. control } \\
\text { vs. Mignone fish }\end{array}$ \\
\hline
\end{tabular}

\footnotetext{
"Mann-Whitney $U$-test.

b n.s., not significant.

'Significantly higher, $p<0.01$, than the compared value.
} 

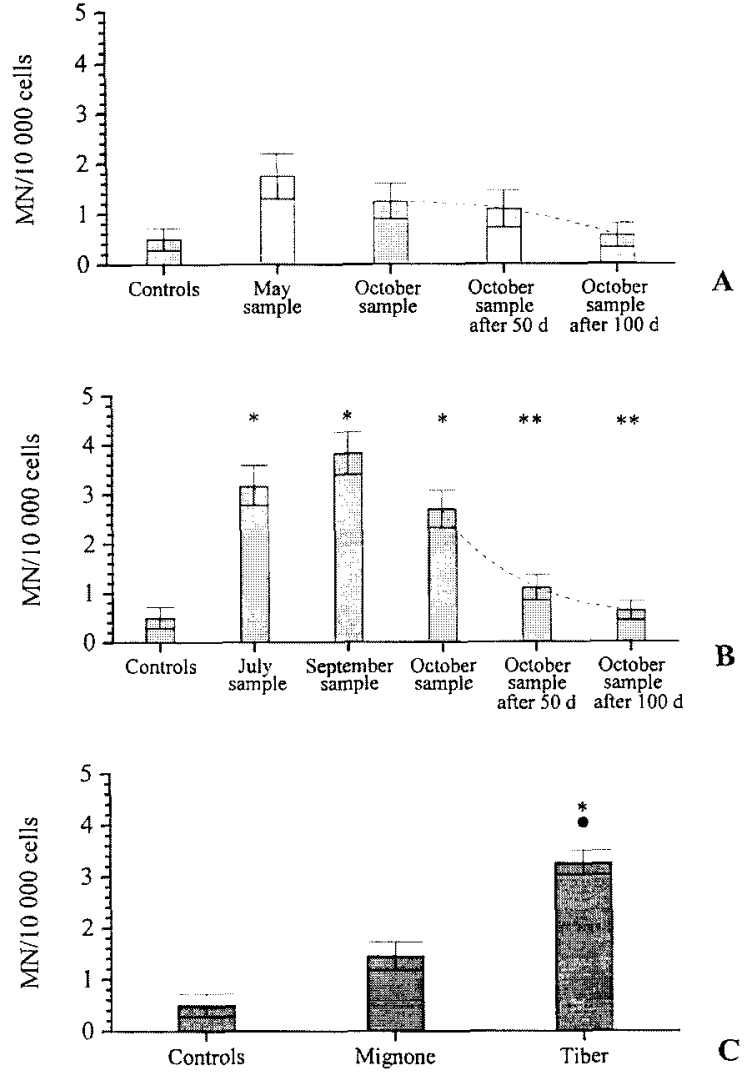

Fig. 3. Mean micronucleus frequencies (MN/10000 erythrocytes) in: (A) wild barbels from the Mignone river (May and October 1993 samples); (B) wild barbels from the Tiber river (July, September and October 1993 samples). In both cases barbels of the October sample were tested for MN at capture, after 50 and 100 days of maintenance in tanks. A total of 10000 erythrocytes per individual were analyzed; and $(\mathrm{C})$ wild barbels from the Mignone river (samples from all seasons pooled) and in wild barbels from the Tiber river (samples from all seasons pooled). Controls are fish obtained by artificial reproduction and maintained in controlled conditions ${ }^{*}$ Micronucleus frequency significantly higher $(p<0.01)$ than the control value, using the MannWhitney $U$-test. ${ }^{* *}$ Micronucleus frequency significantly lower $(p<0.01)$ than the value at capture, using the Mann-Whitney $U$ test. Micronucleus frequency significantly higher $(p<0.01)$ than the Mignone value, using the Mann-Whitney $U$ test.

3B). Barbels of the October sample, examined after maintenance, showed a marked decrease in $\mathrm{MN}$ frequency. Both values (50 and 100 days) were significantly lower than the value observed at capture, while there were no significant differences with respect to the control group.
ANOVA performed, within each river, on fish groups caught in the different months did not detect any seasonal effect. For this reason all fish of each river were pooled, and means for each river were calculated to evaluate differences between the two riverine environments (Fig. 3C). Micronucleus frequency in fish from the Tiber is significantly higher than both the control group and the Mignone group.

\section{Discussion}

The results of the MN test carried out in this study on Barbus plebejus raise several points of interest.

The most remarkable result is that $\mathrm{MN}$ frequency appears to be strongly related to the water quality of the different environments examined. The relationship between MN frequency and pollution levels observed in wild freshwater fish reflects what already observed by different authors in marine fish from coastal areas (Hose et al., 1987; Hughes and Hebert, 1991), besides being in accordance with that observed by means of in situ exposure of rainbow trout to polluted riverine waters (De Flora et al., 1993).

The presence of mutagenic agents in the Tiber was evidenced, in accordance with previous findings, using the MN test on Vicia faba root tips exposed to water and sediments from the Tiber (Rizzoni et al., 1995). On the contrary, the low MN frequencies observed in the Mignone lead to the conclusion that in this river genotoxic agents are not detectable. In fact, the frequencies observed in samples from the Mignone river did not differ significantly from the frequencies of the control group. The low spontaneous MN frequency observed in the latter $(0.5$ $\mathrm{MN} / 10000$ erythrocytes) allows the detection of even a minimal mutagenic effect. Thus, in in situ investigations the $\mathrm{MN}$ frequency in fish from unpolluted environments could represent a useful control reference.

The chance to follow the $\mathrm{MN}$ frequency with repeated blood samplings on the same fish at capture and at different time intervals after maintenance in controlled conditions demonstrated a 'recovery capacity' after removal from the natural environment. This result supports the conclusion that the erythro- 
cyte MN test in fish is indicative of short-term cytogenetic damage. However, further background information is necessary on fish erythrocytes kinetics and on the selection mechanisms against micronucleated erythrocytes.

Notwithstanding the fact that in fish, lower MN frequencies, both spontaneous and induced, can be observed with respect to mammals (Rizzoni et al., 1987), a dose-dependent and time-dependent response has been ascertained by many authors (Hooftman and Vink, 1981; Hose et al., 1984; Das and Nanda, 1986). This confirms the suitability of this test system to study the relationship between pollution levels and mutagenic toxicity. The use of fish as indicator organisms for monitoring the presence of genotoxic contaminants in the environment seems justified because global information on the effects of exposure to a 'complex mixture' such as riverine waters can be obtained. The barbel appears to be a suitable bioindicator species, owing to its benthic behavior and to its wide zoogeographic distribution, in studying genotoxic pollution in middle river courses.

\section{Acknowledgements}

The authors are grateful to Stefano Cataudella for the helpful advice and his continuous support during and after the experiment and for critical reading of the manuscript.

\section{References}

Alink, G.M., E.M.H. Frederix-Wolters, M.A. van der Gaag, J.F.J. van de Kerkhoff and C.L.M. Poels (1980) Induction of sisterchromatid exchanges in fish exposed to Rhine water, Mutation Res., 78, 369-374.

Al-Sabti, K. and C.D. Metcalfe (1995) Fish micronuclei for assessing genotoxicity in water, Mutation Res., 343, 121-135.

Angeletti. C.. V. Carunchio, R. Galvani, I. Nicoletti, N. Pelosi, G. Vinci and L. Zoccolillo (1985) Prime indicazioni dello stato di inquinamento delle acque del Mignone, in: Provincia di Roma - Assessorato Ambiente (Ed.), Valutazione sullo Stato dell' Ambiente nel Bacino Idrografico del Fiume Mignone, pp. 157-160.

Carchini. G.. M. Bazzanti, P. Nicolai, C. Belfiore, R. Fochetti, E. Rota e F. Bambacigno (1985) Popolamento macrobentonico e valutazione biologica della qualità dell' acqua del fiume
Mignone, in: Provincia di Roma - Assessorato Ambiente (Ed.). Valutazione sullo Stato dell' Ambiente nel Bacino Idrografico del Fiume Mignone. pp. 137-152.

Das, R.K. and N.K. Nanda (1986) Induction of micronuclei in peripheral erythrocytes of fish Heteropneustes fossilis by mitomicin $C$ and paper mill effluent. Mutation Res., 175, 67-71.

De Flora, S., L. Viganò, F. D'Agostini, A. Camoirano, M. Bagnasco, C. Bennicelli, F. Melodia and A. Arillo (1993) Multiple genotoxicity biomarkers in fish exposed in situ to polluted river water, Mutation Res.. 319, 167-177.

Fange, R. (1992) Fish blood cells, in: W.S. Hoar, D.J. Randall and A.P. Farrell (Eds.), Fish Physiology, Vol. XII part B, Academic. San Diego, pp. 2-46.

Goksoyr, A.. T. Andersson, D.R. Buhler, J.J. Stegeman, D.E. Williams and L. Forlin (1991) Immunochemical cross-reactivity of $\beta$-naphthoflavone-inducible cytochrome P450 (P450 IA1) in liver microsomes from different fish species and rat, Fish Physiol. Chem., 9, 1-13.

Guzzini, A. and R. Pagnotta (1990) Valutazione della qualità delle acque interne mediante indici biologici: applicazione ai fiumi Tevere ed Aniene, Istituto di Ricerca sulle Acque. Rapporti tecnici, R/132, 46 pp.

Heddle, J.A., M. Hite, B. Kirkhart, K. Mavournin. J.T. MacGregor, G.W. Newell and M.F. Salamone (1983) The induction of micronuclei as a measure of genotoxicity, Mutation Res., 123. $61-118$.

Hooftman, R.N. and G.J. Vink (1981) Cytogenetic effects on the eastern mudminnow, Umbra pygmaea, exposed to ethyl methanesulfonate, benzo(a)pyrene, and river water. Ecotox. Environ. Safety, 5, 261-269.

Hooftman, R.N. and W.K. de Raat (1982) Induction of nuclear anomalies (micronuclei) in the peripheral blood erythrocytes of the eastern mudminnow Umbra pygmaea by ethyl methanesulphonate, Mutation Res., 104, 147-152.

Hose, J.E., J.B. Hannah, H.W. Puffer and M.L. Landolt (1984) Histological and skeletal abnormalities in benzo(a)pyrenetreated rainbow trout alevins, Arch. Environ. Contam. Toxicol., $13,675-684$.

Hose, J.E., J.N. Cross. S.G. Smith and D. Diehl (1987) Elevated circulating erythrocyte micronuclei in fish from contaminated sites off southern California. Mar. Environ. Res., 22, 167-176.

Huet, M. (1949) Aperçu des relations entre la pente et les populations piscicoles dans les eaux courantes, Rev. Suisse Hydrol.. $\mathrm{XI}, 3 / 4$

Hughes, J.B. and A.T. Hebert (1991) Erythrocyte micronuclei in Winter Flounder (Pseudopleuronectes americanus): results of field surveys during 1980-1988 from Virginia to Nova Scotia and in Long Island Sound, Arch. Environ. Contam. Toxicol., $20,474-479$.

Klingerman. A.D.. S.E. Bloom and W.M. Howell (1975) Umbra limi: a model for the study of chromosome aberration in fish, Mutation Res.. 31, 225-233.

Landolt, M.L. and R.M. Kocan (1983) Fish cell cytogenetics: a measure of the genotoxic effects of environmental pollutants. in: J.O. Nriagu (Ed.), Aquatic Toxicology, J. Wiley and Sons, New York, pp. 335-352.

Rizzoni, M., B. Gustavino, C. Ferrari, L.G. Gatti and E.A. Fano 
(1995) An integrated approach to the assessment of the environmental quality of the Tiber river in the urban area of Rome: a mutagenesis assay (micronucleus test) and an analysis of macrobenthic community structure, Sci. Tot. Environ., 162 , 127-137.

Rizzoni, M., E. Vitagliano, M.C. Marconi, A. Sottili and B. Gustavino (1987) Micronuclei induction by low doses of $X$-rays in Vicia faba root tips, Mutation Res., 176, 205-209. Stahl, R. Jr. (1991) The genetic toxicology of organic compounds in natural waters and wastewaters, Ecotoxicol. Environ. Safety, 22, 94-125.

Vindimian, E., P. Namour, B. Migeon and J. Garric (1991) In situ pollution induced cytochrome P450 activity of freshwater fish: Barbel (Barbus barbus), chub (Leuciscus cephalus) and nase (Chondrostoma nasus), Aquat. Toxicol., 21, 255-266.

Woodiwiss, F.S. (1978) Second Technical Seminar - Background Information, Commission of the European Communities, 361 pp. 